\title{
PENATALAKSANAAN BACK MASSAGE DI PANTI TRESNA WERDHA TERATAI KM.5 PALEMBANG TAHUN 2020
}

\author{
Evi Royani \\ Program Studi DIII Keperawatan STIKES Mitra Adiguna Palembang. \\ Komplek Kenten Permai Blok J No 9-12 Bukit Sangkal Palembang 30114 \\ Email : eviroyani73@gmail.com
}

\begin{abstract}
Abstrak
Menurut World Health Organisation (WHO) (2016) 335 juta penduduk di dunia yang mengalami Rematik. Nyeri pada penderita rematik terjadi sebagai akibat spasme otot atau tekanan pada saraf di daerah sendi yang terganggu dan pertumbuhan tulang yang berlebihan sehingga merangsang akar saraf sewaktu keluar dari tulang vertebra. Back Massage adalah salah satu tehnik memberikan tindakan masase pada punggung dengan usapan secara perlahan. Tujuan penelitian ini adalah untuk mengetahui penatalaksanaan back massage di Panti Tresna Werdha Teratai KM.5 Palembang Tahun 2020. Metode penelitian yang digunakan dalam penelitian ini adalah deskriptif kualitatif. Sampel dalam penelitian ini berjumlah 3 orang yaitu 2 orang lansia yang tinggal di Panti Tresna Werdha Teratai KM.5 Palembang dan 1 orang perawat yang bertugas dan berpengalaman minimal 5 tahun di Panti Tresna Werdha Teratai KM.5 Palembang. Pengambil sampel dilakukan dengan teknik purposive sampling. Hasil penelitian didapatkan selama ini penghuni panti sering mengeluh nyeri sendiri terutama pada kaki dan punggung. Saran diharapkan dapat menjadi masukan dalam melakukan pengobatan secara non farmakologi untuk mengatasi masalah nyeri rematik seperti dengan melakukan back massage yang sesuai dengan standar operasional prosedur.
\end{abstract}

Kata Kunci : Rematik, Back Massase

\begin{abstract}
According to the World Health Organization (WHO) (2016) 335 million people in the world experience rheumatism. Pain in patients with rheumatism occurs as a result of muscle spasm or pressure on nerves in the affected joint area and excessive bone growth that stimulates nerve roots as they exit the vertebral column. Back Massage is a technique of providing massage on the back with slow strokes. The purpose of this study was to determine the management of back massage at the Tresna Werdha Teratai Panti KM.5 Palembang in 2020. The research method used in this study was descriptive qualitative. The sample in this study amounted to 3 people, namely 2 elderly people living at the Tresna Werdha Teratai Panti KM.5 Palembang and 1 nurse on duty and at least 5 years of experience at the Tresna Werdha Teratai Panti KM.5 Palembang. Sampling was done by purposive sampling technique. The results of the study showed that during this time the residents of the orphanage often complained of their own pain, especially in the legs and back. Suggestions are expected to be input in carrying out non-pharmacological treatment to overcome rheumatic pain problems such as by doing back massage in accordance with standard operating procedures.
\end{abstract}

Keywords $\quad$ :Rematik, Back Massase

Jurnal Kesehatan dan Pembangunan, Vol. 11, No. 22, Juli 2021 


\section{PENDAHULUAN}

Menua atau menjadi tua adalah suatu keadaan yang terjadi di dalam kehidupan manusia. Proses menua merupakan proses panjang hidup, tidak dimulai dari suatu waktu tertentu, tetapi dimulai sejak permulaan kehidupan. Menjadi tua merupakan proses alamiah, yang berarti seseorang telah melalui tiga tahap kehidupannya, yaitu anak, dewasa dan tua. Tiga tahap ini berbeda, baik secara biologis maupun psikologis. Memasuki usia tua berarti mengalami masa kemunduran fisik yang ditandai dengan kulit yang mengendur, rambut memutih, gigi mulai ompong, pendengaran kurang jelas, penglihatan semakin memburuk, gerakan lambat dan figure tubuh yang tidak proporsional (Nugroho, 2008).

Salah satu penyakit yang sering dikeluhkan lansia adalah penyakit sendi terutama rematik. Rematik adalah penyakit inflamasi sistemik kronis, inflamasi sistemik yang dapat mempengaruhi banyak jaringan dan organ, tetapi terutama menyerang fleksibel (sinovial) sendi. Menurut World Health Organisation (WHO) (2016) 335 juta penduduk di dunia yang mengalami Rematik (Bawarodi, 2017).

Sedangkan prevalensi Rematik tahun 2004 di Indonesia mencapai 2 juta jiwa, dengan angka perbandingan pasien wanita tiga kali lipatnya dari laki-laki. Di Indonesia jumlah penderita Rematik pada tahun 2011 diperkirakan prevalensinya mencapai 29,35\%, pada tahun 2012 prevalensinya sebanyak 39,47\%, dan tahun 2013 prevalensinya sebanyak $45,59 \%$ dan pada tahun 2014 prevalensi Rematik di Sulawesi Utara sebanyak 24,7\%. (Bawarodi, 2017).

Pada tahun 2013, 10 penyakit terbanyak salah satunya adalah Artritis Rheumatoid, prevalensi menurut kelompok umur 55-64 tahun sebanyak 45,0, umur 6574 tahun sebanyak 51,9 dan umur 75 tahun sebanyak 54,8 yang terkena Artritis Rheumatoid. Menurut prevalensinya cukup tinggi dan bervariasi pada setiap Provinsi. Provinsi Riau dengan prevalensi terendah
10,8\% dan Provinsi Nusa Tenggara Timur yang tertinggi $33,1 \%$. Angka Prevalensi di Jawa barat $32,1 \%$. Sedangkan menurut Provinsi Sumatera Selatan Artritis Rheumatoid 15,6\% (Sidik, 2018).

Menurut Dinas Kesehatan Kota Palembang tahun 2013, jumlah angka kejadian rheumatoid artritis adalah 44.200 orang, dan berada diurutan ke 3 dari sepuluh penyakit terbesar. Pada tahun 2014 jumlah angka kejadian rheumatoid artritis 64.852 kebanyakan dari lansia yang mengalami rheumatoid artritis ini dipengaruhi oleh faktor umur dan jenis kelamin, sedangkan pada tahun 2015 angka kejadian artritis rheumatoid adalah 72.675 orang dan berada diurutan ke 3 dari sepuluh penyakit terbesa (Sidik, 2018)

Reumatik atau osteoarthritis merupakan penyakit degeneratif sendi yang disebabkan oleh banyak faktor antara lain: reaksi alergi, infeksi, genetik dan juga karena proses penuaan seseorang. Osteoarthritis yang disebabkan karena proses penuaan seseorang dikarenakan tulang mulai kehilangan kartilago (jaringan tulang rawan) yang berfungsi sebagai bantalan antara tulang dan sendi, yang kemudian semakin tipis sehingga menyebabkan rasa nyeri pada sendi akibat adanya inflamasi ringan yang timbul karena gesekan ujung-ujung tulang penyusun sendi. Di antara tulang-tulang tersebut terdapat suatu lapisan cairan yang disebut cairan sinovial yang berfungsi sebagai bahan pelumas yang mencegah ujung-ujung tulang tersebut bergesekan dan saling mengikis satu sama lain. Gesekan tersebut akan membuat lapisan tersebut semakin tipis dan pada akhirnya akan menimbulkan rasa nyeri (Kristanto, 2017).

Adanya nyeri membuat penderita seringkali takut untuk bergerak sehingga mengganggu aktivitas sehari-hari dan dapat menurunkan produktivitasnya. Disamping itu, dengan mengalami nyeri, sudah cukup membuat pasien frustasi dalam menjalani hidupnya sehari-hari sehingga dapat menggaggu kenyamanan pasien. Karenanya, 
terapi utama yang diarahkan adalah untuk menangani nyeri ini (Kristanto, 2017).

Penanganan sistem nyeri medial (yang memproses aspek emosional dari nyeri seperti ketakutan dan stres) sangat penting pada pasien rematik dibandingkan sistem lateral yang memproses sensasi fisik seperti intensitas, durasi, dan lokasi nyeri, selama episode nyeri. Nyeri pada penderita rematik terjadi sebagai akibat spasme otot atau tekanan pada saraf di daerah sendi yang terganggu dan pertumbuhan tulang yang berlebihan sehingga merangsang akar saraf sewaktu keluar dari tulang vertebra. (Trihartini, 2016).

Back Massage adalah salah satu tehnik memberikan tindakan masase pada punggung dengan usapan secara perlahan. Usapan dengan lotion/balsem memberikan sensasi hangat dengan mengakibatkan dilatasi pada pembuluh darah lokal. Vasodilatasi pembuluh darah akan meningkatkan peredaran darah pada area yang diusap sehingga aktivitas sel meningkat dan akan mengurangi rasa akit serta menunjang proses penyembuhan luka (Kristanto, 2017).

Massase merupakan tehnik integrasi sensoris yang mempengaruhi aktivitas sistem syaraf otonom. Massase punggung merupakan intervensi non farmakologis dengan menggunakan pendekatan secara fisik. Penggunaan massase punggung tidak mempunyai efek samping berarti dan mudah dalam mengaplikasikannya (Kusyanti dalam Achjar, 2016).

Beberapa penelitian juga telah mengidentifikasi manfaat dari massase punggung antara lain penurunan secara bermakna pada intensitas nyeri dan kecemasan serta perubahan positif pada denyut jantung dan tekanan darah, yang mengindikasikan relaksasi pada pasien lansia. Di samping itu penggunaan terapi non farmakologis ini tidak mempunyai efek samping berarti dan mudah dalam pengaplikasiannya. (Trihartini, 2016).

Berdasarkan data yang didapat dari pengambilan data awal di Panti Sosial Tresna
Werdha diketahui bahwa jumlah lanjut usia yang menderita Artritis Rheumatoid pada tahun 2016 yaitu berjumlah 27 orang, tahun 2017 yaitu berjumlah 31 orang, dan pada tahun 2018 sebanyak 35 orang. Lansia yang menetap di Panti Sosial Tresna Werdha hingga Januari 2019 yaitu berjumlah 69 orang, dengan komposisi 45 orang perempuan dan 24 orang laki-laki.

Berdasarkan observasi dari beberapa penderita reumatik yang tinggal di Panti Tresna Werdha Teratai Palembang mereka sering mengalami kaki dan pinggang pegalpegal, nyeri sendi dan otot, saat sehabis melakukan aktivitas atau saat pagi habis bangun tidur, dan hampir semua para penderita reumatik jika penyakitnya kambuh mereka hanya minum obat penghilang rasa nyeri yang diberikan dari petugas panti atau hanya mengoleskan dengan balsem area yang nyeri untuk menghangatkannya bahkan sebagian membiarkan penyakitnya karena menganggap sebagai suatu yang biasa terjadi dan akan hilang dengan sendirinya.

Berdasarkan uraian di atas maka peneliti tertarik untuk melakukan penelitian dengan judul "Penatalaksanaan Back Massage di Panti Tresna Werdha Teratai KM.5 Palembang Tahun 2020".

\section{METODOLOGI PENELITIAN}

\section{Fokus Penelitian}

Fokus penelitian dalam penelitian ini adalah penatalaksanaan back massage di Panti Tresna Werdha Teratai KM.5 Palembang Tahun 2020, berupa studi kasus yang bersifat kualitatif.

Studi kasus pada penelitian ini dilakukan dengan cara meneliti tindakan dari unit tunggal dapat berarti satu orang yang dianalisis baik dari segi berhubungan dengan keadaan tindakan dan reaksi terhadap perlakuan tersebut. Meskipun di dalam studi kasus ini yang diteliti unit tunggal, namun analisis secara mendalam meliputi berbagai aspek yang cukup luas (Danim dan Darwis. 2003). 
Sasaran penelitian ini adalah lansia yang tinggal di Panti Tresna Werdha Teratai KM.5 Palembang dan penelitian ini dilakukan pada tanggal 3 Mei- 10 Mei 2020 di Panti Tresna Werdha Teratai KM.5 Palembang.

\section{Data dan Metode Pengumpulan Data Primer}

Data primer dalam penelitian ini diperoleh dari hasil observasi yang dilakukan peneliti dengan bantuan alat rekam gambaran (video) dan wawancara.

\section{Data Sekunder}

Data sekunder dalam penelitian ini diperoleh dari pihak Panti Tresna Werdha Teratai KM.5 Palembang, media massa berupa internet, dan buku-buku sumber yang berhubungan dengan penelitian ini.

\section{Metode Pengumpulan Data}

Metode pengumpulan data pada penelitian menggunakan wawancara berpedomankan pada pedoman wawancara mendalam dan observasi dengan bantuan alat rekam gambaran (video).

\section{Situasi Sosial dan Sampel \\ Situasi Sosial}

Situasi sosial dalam penelitian ini terdiri tempat di Panti Tresna Werdha Teratai KM.5 Palembang, pelakunya adalah lansia yang tinggal di Panti Tresna Werdha Teratai KM.5 Palembang dan aktivitasnya melakukan wawancara mengenai penatalaksanaan back massage.

\section{Informan}

Informan dalam penelitian kualitatif bukan dinamakan responden tetapi narasumber atau partisipan, informan, teman, guru atau konsultan dalam penelitian. Banyak penelitian kualitatif yang dilakukan terhadap objek penelitian yang dilakukan terhadap seseorang (Satori, 2009).

Informan dalam penelitian ini berjumlah 3 orang yaitu 2 orang lansia yang tinggal di Panti Tresna Werdha Teratai KM.5
Palembang dan 1 orang perawat yang bertugas dan berpengalaman minimal 5 tahun di Panti Tresna Werdha Teratai KM.5 Palembang.

Teknik pengumpulan sampel pada penelitian ini adalah menggunakan non probability sampling. Dalam penelitian ini pengambilan sampel dengan cara purposive sampling

\section{Teknik Analisa Data}

Teknik analisis data dalam penelitian ini akan menggunkan metode seperti yang di kemukakan oleh Miles dan Huberman yang di ungkapkan dalam Basrowi Suwandi (2008) dengan langkah-langkah sebagai berikut:

1. Reduksi data

2. Penyajian data

3. Menarik kesimpulan

4. Verifikasi / pengecekan ulang.

\section{HASIL PENELITIAN DAN PEMBAHASAN}

\section{Hasil Peneitian}

\section{Gambaran Umum Informan}

Pada penelitian ini sampel (partisipan) berjumlah 3 orang yaitu 2 orang lansia yang tinggal di Panti Tresna Werdha Teratai KM.5 Palembang sebagai informan utama dan 1 orang pengurus di Panti Tresna Werdha Teratai KM.5 Palembang sebagai informan kunci. Untuk lebih jelasnya, karakteristik informan dan informan kunci dalam penelitian ini dapat dilihat pada tabel 4.1 berikut ini :

Tabel 4.1

\section{Karakterstik Informan Berdasarkan Umur, Lama Tinggal}

\begin{tabular}{cccc}
\hline Inisial & Umur & Pendidikan & $\begin{array}{c}\text { Lama } \\
\text { Tinggal }\end{array}$ \\
\hline Ny. S & $\begin{array}{c}65 \\
\text { tahun }\end{array}$ & SD & 11 tahun \\
\hline Ny.M & $\begin{array}{c}70 \\
\text { tahun }\end{array}$ & SD & 12 tahun \\
\hline
\end{tabular}


Ny.S berusia 65 tahun, pendidikan terakhir SD, lama tinggal di Panti Tresna Werdha Palembang selama 11 tahun sedangkan Ny.M berusia 70 tahun, pendidikan SD dan lama tinggal di Panti Tresna Werdha Palembang sudah 12 tahun.

Tabel 4.2

\section{Karakterstik Informan Berdasarkan Umur, Pendidikan Dan Pekerjaan}

\begin{tabular}{cccc}
\hline Inisial & Umur & Pendidikan & Pekerjaan \\
\hline $\mathrm{Nn}$. & 21 & DIII & Perawat \\
$\mathrm{PH}$ & tahun & & \\
\hline
\end{tabular}

Dari tabel 4.2 diatas diketahui Nn.PH berusia 21 tahun, pendidikan terakhir DIII, pekerjaan sehari-hari sebagai perawat.

\section{Pembahasan \\ Pertanyaan 1 : Sudah berapa lama ibu tinggal di panti ? \\ Jawaban : Sudah sebelas tahun (Ny.S) Kiro-kir0 \\ duo belas tahun dek aku sudah disini (Ny.M)}

Analisis : Berdasarkan informasi yang didapat dari Ny.S dan Ny.M diketahui bahwa kedua informan tinggal di panti sudah lebih dari 10 tahun.

Pertanyaan 2 : $\quad$ Selama tinggal di panti apakah bapak/ibu pernah mengalami gangguan kesehatan?

Jawaban

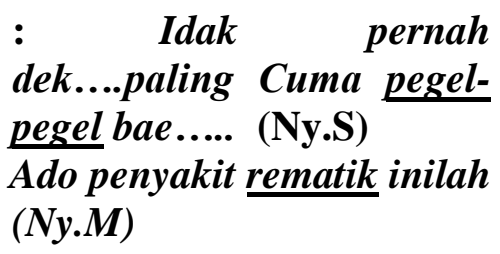

Analisis : Berdasarkan informasi yang didapat dari kedua informan diketahui bahwa kedua informan pernah mengalami pegal-pegal pada daerah sendi
Hal ini sesuai dengan pernyataan informan kunci tentang penyakit yang sering di alami oleh penghuni panti, informan menjelaskan bahwa Macemmacem dek...ado yang rematik, asam urat, darah tinggi. Ado gatel-gatel....

Menurut Bawarodi (2017), salah satu penyakit yang sering dikeluhkan lansia adalah penyakit sendi terutama rematik. Rematik adalah penyakit inflamasi sistemik kronis, inflamasi sistemik yang dapat mempengaruhi banyak jaringan dan organ, tetapi terutama menyerang fleksibel (sinovial) sendi. Menurut World Health Organisation (WHO) 335 juta penduduk di dunia yang mengalami Rematik.

Menurut Khomsan (2017), rematik merupakan penyakit yang menyerang anggota gerak, yaitu sendi, otot, tulang dan jaringan sekitar sendi. Keluhan yang sering muncul adalah nyeri, kaku, bengkak, sampai keterbatasan gerak tubuh. Nyeri pada rematik hampir sama pada saat keselo, namun pada rematik disertai peradangan pada persendian dan kulit terlihat memerah akibat munculnya peradangan.

Pertanyaan 3 : pakah bapak/ibu pernah mengalami nyeri pada anggota tubuh ?

Jawaban : : Iyo pernah dek... (Ny.S)

Analisis Ado (Ny.M)

: Gejala rheumatoid arthritis diantaranya pasien mengeluhkan sakit pada sendi yang disertai rasa panas, nyeri, bengkak, dan warna kemerahan.

Hal ini sesuai dengan pernyataan informan kunci tentang lansia yang mengalami nyeri sendi. Informan menyatakan bahwa "Banyak la dek di tiaptiap kamar itu ado galo...dak biso kito sebutke sikok-sikok.

Menurut informan hal tersebut disebabkan oleh beberapa faktor diantaranya Jurnal Kesehatan dan Pembangunan, Vol. 11, No. 22, Juli 2021 
kurang minum susu kalsium...atau biso jugo mereka galak mandi malem......

Menurut Kristanto (2017), reumatik atau osteoarthritis merupakan penyakit degeneratif sendi yang disebabkan oleh banyak faktor antara lain: reaksi alergi, infeksi, genetik dan juga karena proses penuaan seseorang. Osteoarthritis yang disebabkan karena proses penuaan seseorang dikarenakan tulang mulai kehilangan kartilago (jaringan tulang rawan) yang berfungsi sebagai bantalan antara tulang dan sendi, yang kemudian semakin tipis sehingga menyebabkan rasa nyeri pada sendi akibat adanya inflamasi ringan yang timbul karena gesekan ujung-ujung tulang penyusun sendi. Di antara tulang-tulang tersebut terdapat suatu lapisan cairan yang disebut cairan sinovial yang berfungsi sebagai bahan pelumas yang mencegah ujung-ujung tulang tersebut bergesekan dan saling mengikis satu sama lain. Gesekan tersebut akan membuat lapisan tersebut semakin tipis dan pada akhirnya akan menimbulkan rasa nyeri.

Menurut Khomsan (2016), penyebab rematik bervariasi. Umumnya, dipengaruhi oleh masalah autoimun, yaitu sistem kekebalan tubuh berbalik menyerang jaringan persendian. Akibatnya, tulang rawan di sekitar sendi menipis. Sebagai gantinya, muncullah tulang baru. Disaat tubuh bergerak, tulang-tulang dipersendian bersinggungan. Kejadian inilah yang memicu rasa sakit dan nyeri yang tak tertahankan.

Pertanyaan 4 : Pada tubuh bagian mana yang sering bapak/ibu rasakan nyeri?

Jawaban : Di kaki, punggung ini nah...galak sering sakit....ngilu (Ny.S)

Di kaki samo pergelangan kaki... (Ny.M)

Analisis : Gejala rheumatoid arthritis diantaranya pasien mengeluhkan sakit pada sendi yang disertai rasa panas, nyeri, bengkak, dan warna kemerahan.

Menurut Langow (2018), menjelaskan bahwa gejala rheumatoid arthritis diantaranya pasien mengeluhkan sakit pada sendi yang disertai rasa panas, nyeri, bengkak, dan warna kemerahan. Rasa nyeri ini menyerang sendi-sendi kecil, seperti buku-buku jari dan pergelangan tangan, kaku sendi terutama terjadi pada pagi hari dan membaik dengan aktivitas sehari-hari. Serta mengalami kelelahan dan kesulitan melakukan aktivitias.

Pertanyaan 5 : Pada saat kapan nyeri itu timbul?

Jawaban : Kalo cuaca dingin dek... (Ny.S)

Kalo habis kerjo berat samo cuaca dingin (Ny.M)

Analisis : Rematik dapat menyebabkan nyeri pada daerah sendi yang disebabkan oleh beberapa faktor diantaranya faktor cuaca dingin dan pekerjaan.

Pertanyaan 6 : Apa yang bapak/ibu lakukan untuk mengatasi nyeri tersebut?

Jawaban : Minum obat (Ny.S)

Aku kasih minyak gosok itulah.... (Ny.M)

Analisis : Penggunaan lotion diharapkan memberikan sensasi hangat dan mengakibatkan vasodilatasi lokal sehingga meningkatkan peredaran darah pada area yang diusap sehingga aktivitas sel meningkat dan akan mengurangi rasa sakit.

Hal ini sesuai dengan pernyataan informan kunci yang menyatakan bahwa Biasonyo nenek itu minum obat untuk tulang itu...samo galak kami kasih balsem.... 
Menurut Yanti (2015), menjelaskan bahwa fisioterapi berperan penting pada penatalaksanaan osteoartritis, yang meliputi pemakaian panas dan dingin dan program latihan yang tepat. Pemakaian panas yang sedang diberikan sebelum latihan untuk mengurangi rasa nyeri dan kekakuan. Pada sendi yang masih aktif sebaiknya diberi dingin dan obat-obat gosok jangan dipakai sebelum pamanasan. Berbagai sumber panas dapat dipakai seperti Hidrokolator, bantalan elektrik, ultrasonic, inframerah, mandi paraffin dan mandi dari pancuran panas. Program latihan bertujuan untuk memperbaiki gerak sendi dan memperkuat otot yang biasanya atropik pada sekitar sendi osteoartritis. Latihan isometric lebih baik dari pada isotonic karena mengurangi tegangan pada sendi. Atropi rawan sendi dan tulang yang timbul pada tungkai yang lumpuh timbul karena berkurangnya beban ke sendi oleh karena kontraksi otot. Oleh karena otototot periartikular. memegang peran penting terhadap perlindungan rawan sendi dari beban, maka penguatan otot-otot tersebut adalah penting.

Pertanyaan 7 : Apakah bapak/ibu pernah melakukan pijat punggung dan cara melakukan pijat punggung

\section{Jawaban : Idak pernah (Ny.S) Idak pernah...yo paling di pijet dewek.... (Ny.M)}

Analisis $\quad: \quad$ Pijat merupakan suatu pijatan yang dilakukan untuk membantu mempercepat proses pemulihan beberapa macam penyakit dengan menggunakan sentuhan tangan dan tanpa masukan obat ke dalam tubuh

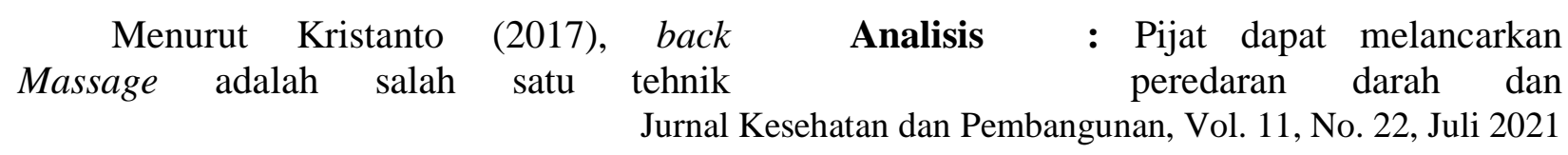

memberikan tindakan masase pada punggung dengan usapan secara perlahan. Usapan dengan lotion/balsem memberikan sensasi hangat dengan mengakibatkan dilatasi pada pembuluh darah lokal. Vasodilatasi pembuluh darah akan meningkatkan peredaran darah pada area yang diusap sehingga aktivitas sel meningkat dan akan mengurangi rasa akit serta menunjang proses penyembuhan luka.

Sedangkan menurut Kusyanti dalam Achjar (2016), massase merupakan tehnik integrasi sensoris yang mempengaruhi aktivitas sistem syaraf otonom. Massase punggung merupakan intervensi non farmakologis dengan menggunakan pendekatan secara fisik. Penggunaan massase punggung tidak mempunyai efek samping berarti dan mudah dalam mengaplikasikannya.

Pertanyaan 8 : Jika belum, apakah bapak/ibu bersedia untuk dilakukan pijat punggung?

$\begin{array}{clr}\text { Jawaban } & \text { : Iyo bersedia dek.. (Ny.S) } \\ & \text { Idak dek...lajulah... } \\ & (\text { Ny.M }) & \\ \text { Analisis } & \text { : Pijat merupakan suatu } \\ & \text { pijatan yang dilakukan } \\ & \text { untuk } & \text { membantu } \\ & \text { mempercepat proses } \\ & \text { pemulihan r beberapa } \\ & \text { macam penyakit dengan } \\ & \text { menggunakan sentuhan } \\ & \text { tangan dan tanpa masukan } \\ & \text { obat ke dalam tubuh }\end{array}$
Pertanyaan 9 : Apa yang bapak/ibu rasakan setelah dilakukan pijat punggung?
Jawaban : Agak enakan dek....badan jadi enteng rasonyo .... (Ny.S)
Alhamdulillah lemak jugo dek....nyerinyo berkurang (Ny.M)

Pijat dapat melancarkan , Vol. 11, No. 22, Juli 2021 
membuat rasa nyaman dan membuat tubuh menjadi lebih rileks.

Pertanyaan 10 : Bagaimana rasa nyeri yang bapak/ibu rasakan sebelum dan setelah dilakukan pijat punggung?

Jawaban

$$
\begin{aligned}
& \text { : Idak pernah dek....di } \\
& \text { pijet-pijet cak itu....। } \\
& \text { (Ny.S). Adolah enaknyo } \\
& \text { dikit....nyeri nyo agak } \\
& \text { berkurang(Ny.M) }
\end{aligned}
$$

$\begin{array}{ll}\text { Analisis } & \begin{array}{l}\text { Manfaat atau efek masase } \\ \text { diantaranya rapat }\end{array} \\ \text { memperlancar peredaran } \\ \text { darah, } & \text { membantu } \\ \text { pembentukan penerapan } & \text { dan pembuangan sisa-sisa, } \\ & \text { pembakaran dalam } \\ & \text { jaringan-jaringan, massage } \\ & \text { juga membantu pengaliran } \\ & \text { cairan lympa lebih cepat. }\end{array}$

Hal ini sesuai dengan pernyataan informan kunci tentang manfaat pijat punggung bahwa Lemaklah biar otot nyo itu idak kenceng lagi....agak mendingan.

Menurut Thihartini (2016), menjelaskan bahwa beberapa penelitian juga telah mengidentifikasi manfaat dari massase punggung antara lain penurunan secara bermakna pada intensitas nyeri dan kecemasan serta perubahan positif pada denyut jantung dan tekanan darah, yang mengindikasikan relaksasi pada pasien lansia. Di samping itu penggunaan terapi non farmakologis ini tidak mempunyai efek samping berarti dan mudah dalam pengaplikasiannya.

Menurut Achjar (2015), massase merupakan tehnik integrasi sensoris yang mempengaruhi aktivitas sistem syaraf otonom. Massase punggung merupakan intervensi non farmakologis dengan menggunakan pendekatan secara fisik. Penggunaan massase punggung tidak mempunyai efek samping berarti dan mudah dalam mengaplikasikannya. Penggunaan lotion diharapkan memberikan sensasi hangat dan mengakibatkan vasodilatasi lokal sehingga meningkatkan peredaran darah pada area yang diusap sehingga aktivitas sel meningkat dan akan mengurangi rasa sakit.

Massase tidak secara spesifik menstimulasi reseptor tidak nyeri pada bagian reseptor yang sama seperti reseptor nyeri tetapi dapat mempunyai dampak melalui sistem kontrol desenden, yaitu sistem serabut berasal dalam otak bagian bawah dan bagian tengahterutama periaqueductal gray matter dan berakhir pada serabut interneuronal inhibitor dalam kornu dorsalis dari medula spinalis. Massase dapat menstimulasi proses endorfin dalam sistem kontrol desenden sehingga mengurangi persepsi nyeri, impuls nyeri dapat diatur atau dihambat oleh mekanisme pertahanan di sepanjang sistem saraf pusat. Pemberian tehnik stimulasi kutan yang dilakukan pada pijatan punggung lansia, menstimulasi ujung ujung saraf yang ada di permukaan tubuh yang diharapkan akan member ujung ujung saraf yang ada di permukaan tubuh yang diharapkan akan memberikan impuls yang lebih kuat daripada impuls nyeri sehingga diharapkan dapat menurunkan impuls nyeri pada lansia. (Achjar, 2015).

Menurut (Maliya, 2015), masase punggung berpengaruh terhadap intensitas nyeri rematik pada lansia. Pijat punggung memberikan efek penurunan kecemasan dan ketegangan otot. Rangsangan pijat otot ini di perkaya akan merangsang serabut saraf deltaA dan serabut $C$ serta melepaskan substansi $P$ pada saraf aferen, dimana terdapat mekanreseptor (alat peraba: kulit) sebagai mekanisme pertahanan, serta pada pusat korteks saraf desenden melepaskan opiate endogen yaitu hormone endorphin sebagai penghilang rasa sakit. Sehingga mampu memblok atau menurunkan impuls nyeri. Pijat adalah stimulus kulit tubuh secara umum, dipusatkan pada punggung dan bahu, atau dapat dilakukan pada satu atau beberapa bagian tubuh dan dilakukan sekitar 30 menit masingmasing bagian tubuh untuk mencapai hasil relaksasi yang maksimal. 
Hasil penelitian ini sejalan dengan penelitian Siahaan (2017) yang berjudul efektivitas pijat punggung terhadap intensitas nyeri rematik sedang pada wanita lanjut usia di Desa Karyawangi Kabupaten Bandung Barat. Kesimpulan dari penelitian ini adalah terdapat penurunan yang signifikan terhadap penurunan skala nyeri rematik pada wanita lanjut usia di Desa Karyawangi Kabupaten Bandung Barat.

Hasil penelitian ini juga sejalan dengan penelitian Trihartini (2015) yang berjudul stimulasi kutaneus slow-stroke back massage menurunkan intensitas nyeri osteoartritis pada lansia. Hasil penelitian didapatkan saat pre-test seluruh responden mengalami nyeri pada tingkat sedang, dan setelah di berikan stimulasi kutaneus: slowstroke back massage tingkat nyeri 9 responden mengalami penurunan menjadi tingkat ringan dan 6 orang responden dengan intensitas nyeri tetap. Dapat disimpulkan bahwa pemberian stimulasi kutaneus: slowstroke back massage mempunyai pengaruh terhadap intensitas nyeri osteoathritis pada lansia di Panti Werdha Hargo Dedali Surabaya.

Berdasarkan hasil penelitian dan pembahasan diatas peneliti berasumsi bahwa selama ini penghuni panti sering mengeluh nyeri sendiri terutama pada kaki dan punggung. Biasanya mereka melakukan pengobatan dengan memberi obat gosok atau balsem untuk menghangatkan bagian tubuh yang nyeri. Dari hasil wawancara dengan pengurus panti diketahui bahwa selama ini pengurus panti tidak pernah menerapkan terapi pijat punggung. Pengurus panti hanya melakukan pemijatan jika ada penghuni panti yang meminta bantuannya untuk melakukan pemijatan dan hal tersebut dilakukan tidak berdasarkan standar operasional prosedur (SOP) pemijatan.

\section{PENUTUP}

\section{Kesimpulan}

Berdasarkan hasil penelitian yang dilakukan dapat disimpulkan sebagai berikut:
1. Selama ini penghuni panti sering mengeluh nyeri sendiri terutama pada kaki dan punggung. Biasanya mereka melakukan pengobatan dengan memberi obat gosok atau balsem untuk menghangatkan bagian tubuh yang nyeri.

2. Pengurus panti selama ini tidak pernah menerapkan terapi pijat punggung. Pengurus panti hanya melakukan pemijatan jika ada penghuni panti yang meminta bantuannya untuk melakukan pemijatan dan hal tersebut dilakukan tidak berdasarkan standar operasional prosedur (SOP) pemijatan

\section{Saran \\ Bagi Panti Jompo Tresna Werda Palembang}

Hasil penelitian ini diharapkan dapat menjadi masukan dalam melakukan pengobatan secara non farmakologi untuk mengatasi masalah nyeri rematik dan dapat diajarkan kepada seluruh penghuni panti agar mereka dapat menerapkannya kepada sesama penghuni panti yang mengalami nyeri rematik.

\section{Bagi Peneliti Selanjutnya}

Diharapkan peneliti selanjutnya dapat melakukan penelitian dengan menggunakan sampel yang lebih banyak lagi sehingga bisa dilihat perbandingannya dan diharapkan mendapatkan hasil yang lebih baik lagi.

\section{DAFTAR PUSTAKA}

Achjar, Komang Ayu. 2016. Terapi musik dan masase punggung terhadap intensitas nyeri sendi lansia.

Andarmoyo. 2013. Perilaku Dengan Kejadian Penyakit Rematik Pada Usia 40-60tahun Behavior With Rheumatic Disease Occurrence Of Age 40-60

Arikunto. 2006. Konsep dan penerapan metodologi penelitian keperawatan. Jakarta. 
Azwar. 2006. Definisi Lanjut Usia. http://www.duniasehat.com,diakses 20 Januari 2018

Bawarodi. 2017. Faktor-Faktor Yang Berhubungan Dengan Kekambuhan Penyakit Rematik Di Wilayah Puskesmas Beo Kabupaten Talaud

Effendi. 2009. Batasan umur lansia. http:www.lanjutusia.com, diakses 25 Januari 2018

Hembing, Wijayakusuma. 2015. Atasi asam urat dan rematik. Jakarta : Puspa Swara.

Hutapea. 2005. Lanjut usia. http://www.gerontik004.com, diakses 20 Januari 2018

Khomsan, Ali. 2017. Terapi jus untuk rematik dan asam urat.

Kristanto. 2017. Pengaruh Terapi Back Massage Terhadap Intensitas Nyeri Reumatik Pada Lansia Di Wilayah Puskemas Pembantu Karang Asem

Kusyati, E. 2006. Ketrampilan dan Prosedur Laboratorium.Jakarta: EGC

Langow. 2018. A to Z Penyakit Rematik Autoimun. Jakarta : Kompas Gramedia

Lusiana. 2015. Prosedur Keperawatan. Yogyakarta : TIM

Maliya. 2015. Effektifitas Senam Rematik Terhadap Kemampuan Berjalan Dengan Nyeri Sendi Untuk Mencapai Hidup Yang Sehat Dan Sejahtera Pada Lanjut Usia

Maryam, Siti. 2008. Mengenal usia lanjut dan perawatannya. Jakarta: Salemba Medika

Notoatmojo. 2012. Metodelogi penelitian. Jakarta : Salemba Medika.

Nugroho, Wahyudi. 2008. Keperawatan Gerontik \& Geriatrik. Edisi ke 3. Jakarta EGC

Panti Tresna Werdha Teratai Palembang. 2019. Jumlah penderita rematik

Pupung. 2009. Pengaruh Teknik Imaginasi Terbimbing Untuk Menurunkan Intensitas Nyeri Pada Pasien Arthitis Rhemathoid (Studi Kasus Panti Werdha Surabayatimur
Saryono. 2011. Metodologi penelitian kebidanan DIII, DIV, S1 dan S2. Yogyakarta : Nuha Medika

Siahaan. 2017. Efektivitas Pijat Punggung Terhadap Intensitas Nyeri Rematik Sedang Pada Wanita Lanjut Usia Di Desa Karyawangi Kabupaten Bandung Barat

Siahaan. 2017. Efektivitas Pijat Punggung Terhadap Intensitas Nyeri Rematik Sedang Pada Wanita Lanjut Usia Di Desa Karyawangi Kabupaten Bandung Barat. Jurnal Skolastik Keperawatan Vol. 3, No.1 Januari Juni 2017

Sidik. 2018. Pengalaman Lansia Dalam Mengatasi Nyeri Arthritis Rheumatoid Di Panti Sosial Tresna Werdha Sumatera Selatan Tahun 2017

Trihartini, Mira. 2016. Stimulasi Kutaneus Slow-Stroke Back Massage Menurunkan Intensitas Nyeri Osteoartritis Pada Lansia. Jurnal Ners Vol. 5 No. 1 April 2010: 87-92

Wahyudi. 2000. Definisi lansia menurut $U U$ No.4 tahun 1945.

Wiyoto. 2011. Gambaran Aktivitas Fisik Lansia Dalam Mengurangi Nyeri Berulang Akibat Rematik Di Desa Balongan Wilayah Kerja Puskesmas Balongan Kecamatan Balongan Kabupaten Indramayu Tahun 2016

Yudiyanta. 2015. Assessment Nyeri. Jurnal CDK-226/ vol. 42 no. 3 , th. 2015 